\title{
PERANAN SISTEM PENGENDALIAN MANAJEMEN TERHADAP KINERJA UNIT PEMBANGKITAN SAGULING
}

\author{
Oleh: \\ Anike Putri \\ Fakultas Ekonomi dan Bisnis, Universitas Informatika dan Bisnis Indonesia \\ email: anikeptr96@gmail.com
}

\begin{abstract}
ABSTRAK
Penelitian ini bertujuan untuk mengetahui peranan sistem pengendalian manajemen terhadap kinerja Unit Pembangkitan Saguling. Penelitian ini dilakukan pada Unit Pembangkitan Saguling. Metode penelitian yang digunakan pada penelitian ini adalah metode deskriptif kualitatif. Data yang digunakan adalah data primer. Data primer bersumber dari hasil observasi, dokumentasi, dan wawancara. Berdasarkan hasil penelitian, disimpulkan bahwa sistem pengendalian manajemen berperan terhadap kinerja Unit Pembangkitan Saguling.
\end{abstract}

Kata Kunci: Sistem Pengendalian Manajemen, Kinerja

\begin{abstract}
The research aims to examine the role of management control system towards Unit Pembangkitan Saguling performance. This research was conducted in Unit Pembangkitan Saguling. The method used in this research is qualitative descriptive method. The data used are primary data. Primary data sourced from the result of observation, documentation, and interview. Based on the result of research, it concludes that the management control system has a role towards Unit Pembangkitan Saguling performance.
\end{abstract}

Keywords: Management Control System, Performance

\section{PENDAHULUAN}

Pemerintah Indonesia yang dinyatakan oleh Presiden Joko Widodo melakukan upaya menambah ketersediaan listrik yang mencukupi, yaitu dengan membuat program pembangunan kelistrikan. Dan program tersebut dikenal dengan program pembangunan listrik 35.000 megawatt (MW). Ketika dicanangkannya program pembangunan listrik oleh pemerintah tersebut, didapat informasi bahwa pembangunan kelistrikan ini telah menimbulkan pertentangan atau terjadi silang pendapat, antara mantan Menteri Koordinator Kemaritiman Rizal Ramli dan mantan Wakil Presiden Jusuf Kalla. Silang pendapat ini menurut mantan Menko Kemaritiman tersebut menyatakan bahwa target pembangunan kelistrikan 35.000 MW dianggap tidak realistis.

Seiring berjalannya waktu, Presiden melakukan reshuffle kabinet dan salah satu Menteri yang diganti dalam reshuffle yang kedua ini salah satunya adalah Menteri 
Koordinator Kemaritiman Rizal Ramli. Digantinya Menko Kemaritiman ini, kemungkinan dengan salah satu sikapnya yang menyatakan bahwa program listrik 35.000 MW ini dianggap tidak realistis. Anggapan tidak realistis ini bisa diartikan terhadap banyak hal kemungkinan, diantaranya adalah kemungkinan kurangnya ketersediaan dana, atau kemungkinan tidak memperhitungkannya kesulitan memperoleh lahan atau tanah untuk lokasi pembangunan, serta masih banyak kemungkinan lainnya yang tentunya diluar pengetahuan yang dimiliki penyusun.

Silang pendapat ini menjadikan sebuah fenomena yang menarik bagi penyusun untuk melakukan penelitian. Tentunya penelitian yang dilakukan, khusus terhadap masalah yang sesuai dengan program studi, yaitu dibidang studi akuntansi. Jadi yang penyusun teliti adalah arti tidak realistis dari kemungkinan, sudut pandang, atau anggapan bahwa perusahaan yang akan memikul beban program kelistrikan tersebut tidak memiliki kinerja baik, sehingga target pencapaian tujuan diragukan.

Apabila program listrik $35.000 \mathrm{MW}$ ini direalisasikan, maka menjadi tanggung jawab Kementerian Energi dan Sumber Daya Mineral, dan dalam pelaksanaannya tentu akan dilakukan oleh sebuah perusahaan milik pemerintah/negara, dalam hal ini perusahaan yang dimaksud adalah PT
PLN (Persero), karena PT PLN (Persero) merupakan Badan Usaha Milik Negara (BUMN) dibidang kelistrikan. Sedangkan teknis pelaksanaannya akan dilakukan oleh salah satu perusahaan pembangkitan kelistrikan yang ada, yaitu PT Indonesia Power, atau disingkat IP. PT Indonesia Power merupakan sebuah anak perusahaan PT PLN (Persero) yang menjalankan usaha komersial pada bidang pembangkitan tenaga listrik. Saat ini PT Indonesia Power merupakan perusahaan pembangkitan listrik dengan daya mampu terbesar di Indonesia. PT Indonesia Power membawahi unit-unit pembangkitan, salah satunya adalah Unit Pembangkitan (UP) Saguling.

UP Saguling adalah sebuah organisasi/perusahaan, karena UP Saguling ini merupakan sebuah wadah sekelompok orang untuk mencapai suatu tujuan yaitu bertujuan menyediakan tenaga listrik melalui suatu proses yang disebut dengan pembangkitan tenaga listrik. Sebab sebagaimana diketahui bahwa organisasi adalah sekelompok orang dalam suatu wadah untuk tujuan bersama. Sama halnya dengan perusahaan, karena perusahaan juga terdiri dari sekelompok orang yang bekerja sama agar tercapai tujuan perusahaan yang telah ditetapkan sesuai dengan rencana. Dalam teori dikatakan bahwa setiap pihak yang mendirikan atau membentuk suatu perusahaan adalah merupakan usaha pihak tersebut untuk tujuan memperoleh 
keuntungan. Dan keuntungan ini merupakan tujuan utama perusahaan tersebut. Setiap perusahaan tentu dalam menjalankan aktivitasnya untuk menghasilkan laba atau keuntungan demi mempertahankan kelangsungan perusahaan.

Setiap pihak yang membentuk atau mendirikan perusahaan adalah merupakan usaha pihak tersebut dalam upaya mencapai tujuan untuk memperoleh keuntungan. Jadi dengan demikian keuntungan itu dijadikan tujuan yang utama. Sebab dari keuntungan inilah yang pada akhirnya dapat memuaskan seluruh orang, atau pihak yang terlibat dalam perusahaan tersebut. Adapun pihakpihak yang terlibat dalam perusahaan, antara lain pihak penanam modal. Penanam modal sangat diperlukan, sebab dalam mendirikan dan menjalankan perusahaan tidak terlepas dari kebutuhan dana, guna membiayai pembangunan fisik perusahaan, maupun untuk keperluan modal kerja dalam menggerakan atau menjalankan proses produksi. Proses produksi dapat berjalan, apabila tersedia bahan baku (raw material) tertentu, kemudian pegawai (labor) yaitu orang yang dengan keahlian tertentu dapat membuat barang tertentu, sesuai dengan bidang usaha perusahaan tersebut. Dan juga untuk biaya-biaya tidak langsung (overhead). Selanjutnya apabila keuntungan yang diperoleh mampu menutupi seluruh beban-beban perusahaan, dan juga mampu memuaskan seluruh pihak yang berkepentingan terhadap perusahaan tersebut, maka kelangsungan hidup perusahaan akan terjaga, atau mungkin akan terus berkembang menjadi sebuah perusahaan yang besar.

$$
\text { Terjaga tidaknya kelangsungan }
$$
hidup perusahaan, dan berkembang tidaknya perusahaan akan sangat bergantung kepada pencapaian tujuan dalam memperoleh keuntungan. Tercapai tidaknya tujuan perusahaan akan sangat bergantung kepada cara seorang manajer mengelola perusahaan. Oleh sebab itu, seorang manajer didalam memimpin sebuah perusahaan memerlukan sebuah alat, guna mengendalikan perusahaan agar seluruh operasi perusahaan mengarah kepada tujuan yang hendak dicapai sesuai dengan rencana yang telah ditetapkan. Keberhasilan maupun kegagalan dalam pelaksanaan, adalah gambaran baik atau buruknya kinerja dan kemampuan yang dimiliki seorang manajer dalam mengendalikan dan mengawasi perusahaan tersebut.

Pada awal didirikan, biasanya masih merupakan perusahaan kecil dengan permasalahan yang dihadapi belum meluas dan kompleks, serta beban kegiatan yang dihadapi masih rendah. Sehingga jumlah pegawai yang ada masih rendah atau sedikit, karena sedikit banyaknya jumlah pegawai akan sebanding dengan tinggi rendahnya beban kegiatan operasi perusahaan. Pada perusahaan seperti ini atau perusahaan skala 
kecil tentunya seorang manajer masih mampu mengendalikan dan mengawasi perusahaan yang dipimpinnya oleh seorang diri.

Berbeda dengan seorang manajer pada perusahaan berskala besar dengan permasalahan yang dihadapi sangat luas dan kompleks, hal ini menyebabkan beban kerja yang sangat tinggi serta memerlukan penanganan operasi secara cepat dan tepat. Disamping itu karena luasnya operasi perusahaan, baik luas aktivitas bidangbidang kegiatan, dengan sendirinya mengakibatkan operasi perusahaan dilakukan oleh jumlah pegawai yang banyak atau tinggi.

Tinggi rendahnya jumlah pegawai disesuaikan dengan perbandingan beban kerja yang dipikul dengan batas maksimal kemampuan menanggung beban kerja untuk setiap pegawai. Dengan demikian perusahaan skala besar tentunya terjadi pendelegasian tugas, wewenang, dan tanggung jawab kepada banyak pegawai, didalam keadaan demikian seorang manajer sangat membutuhkan suatu alat untuk mengendalikan seluruh kegiatan perusahaan agar mengarah kesatu tujuan yang telah ditetapkan sesuai dengan rencana. Dan alat tersebut adalah sistem pengendalian manajemen.

Kinerja merupakan suatu prestasi atau tingkat keberhasilan yang dicapai oleh individu atau suatu organisasi, dalam melaksanakan pada suatu periode tertentu. Salah satu alat organisasi yang penting untuk menunjang kinerja yang optimal dari sebuah perusahaan adalah dibutuhkannya suatu sistem pengendalian manajemen (Porporato, 2006). Untuk menentukan keberhasilan dan juga untuk pengembangan ke depannya, maka perusahaan harus memiliki suatu sistem yang memadai serta tenaga kerja yang berkualitas. Adapun sistem yang dimaksud adalah sistem pengendalian manajemen yang memadai.

Berdasarkan latar belakang penelitian yang telah diuraikan diatas, maka permasalahan dapat diidentifikasi sebagai berikut:

1. Apakah implementasi sistem pengendalian manajemen telah memadai di Unit Pembangkitan Saguling.

2. Bagaimana kinerja di Unit Pembangkitan Saguling.

3. Apakah implementasi sistem pengendalian manajemen berperan dalam pencapaian kinerja di Unit Pembangkitan Saguling.

\section{KERANGKA TEORITIS}

\section{Tinjuan Pustaka}

Sistem pengendalian manajemen adalah suatu mekanisme baik formal maupun informal yang didesain untuk menciptakan kondisi yang mampu meningkatkan peluang pencapaian harapan output yang diinginkan dengan 
memfokuskan pada tujuan yang akan dicapai oleh perusahaan dan perilaku yang diinginkan (Porporato, 2006). Pengendalian manajemen adalah suatu proses yang dilakukan oleh manajemen suatu organisasi untuk menjamin sumber daya yang diperoleh digunakan secara efektif dan efisien dalam usaha mencapai tujuan organisasi (Tatikonda dan Tatikonda, 1998).

Dan sebagaimana diketahui dari uraian-uraian sebelumnya, bahwa sistem pengendalian manajemen merupakan alat bagi manajer agar seluruh sumber daya yang dimiliki dalam organisasi dapat berkontribusi dalam pencapaian tujuan sesuai dengan rencana yang telah ditetapkan.

Kinerja merupakan gambaran mengenai sejauhmana keberhasilan atau kegagalan suatu organisasi dalam menjalankan tugas dan fungsi pokoknya dalam rangka mewujudkan sasaran, tujuan, misi, serta visinya (Zhang dan McCullough, 2001). Pengukuran kinerja adalah penilaian kinerja, baik pengukuran kinerja finansial maupun non finansial yang merupakan komponen yang sangat penting dalam sistem pengendalian manajemen.

Jadi dengan demikian dari uraian diatas dapat ditarik suatu kesimpulan, bahwa hubungan sistem pengendalian manajemen dengan kinerja adalah hukum sebab dan akibat, yaitu dua hal yang saling berkaitan atau berhubungan, sebab baik buruknya kinerja yang dicapai oleh seluruh anggota organisasi merupakan gambaran terpenuhi tidaknya, atau memadai tidaknya seluruh unsur-unsur sistem pengendalian manajemen yang diterapkan dalam perusahaan secara konsekuen. Karena sistem pengendalian manajemen adalah alat yang dapat berperan guna mengarahkan seluruh anggota organisasi dalam pelaksanaan tugasnya agar fokus kepada tujuan yang telah ditetapkan sesuai dengan rencana.

Jadi apabila unsur-unsur sistem pengendalian manajemen terpenuhi atau memadai, maka akan meningkatkan kinerja para pelaksana tugas (kinerja baik). Arti kinerja baik adalah hasil pelaksanaan tugas sesuai dengan yang direncanakan. Sedangkan, apabila tidak terpenuhinya unsur-unsur sistem pengendalian manajemen, pencapaian kinerja akan sebaliknya (kinerja buruk).

Dari ulasan diatas mengenai hubungan sistem pengendalian manajemen dengan kinerja dapat disimpulkan bahwa sistem pengendalian manajemen sangat erat kaitannya dengan kinerja.

Apabila penyusun mengumpamakan perusahaan adalah sebuah bangunan, maka sistem pengendalian manajemen itu adalah sama dengan pondasi sebuah bangunan. Sebuah bangunan akan kuat dan kokoh apabila pondasi sebagai penopang bangunan tersebut dibuat dengan dipenuhinya unsur- 
unsur bahan pondasi yang diperlukan, seperti kerangka pembesiannya memakai besi beton berukuran sesuai untuk bobot berat bangunan yang akan ditopang. Begitupun dengan takaran bahan-bahan lain sebagai campuran untuk pengecoran beton (semen, pasir, batu split/batu kerikil kecil, dan air) harus sesuai dengan ukuran yang ditentukan ahli bangunan. Apabila pembuatan pondasi sesuai dengan unsurunsur yang disyaratkan maka akan diperoleh bangunan yang berdiri kuat dan kokoh, hal ini sesuai tujuan sebagaimana yang diinginkan oleh pembuat sebagai pelaksana pekerjaan dan pemilik bangunan.

Jadi dengan demikian, bahwa sistem pengendalian manajemen merupakan suatu alat penopang dalam pencapaian tingkat keberhasilan (kinerja) para anggota organisasi dalam melaksanakan tugasnya, guna tercapainya keuntungan sebagai tujuan perusahaan.

\section{METODE PENELITIAN}

Dalam penelitian ini yang menjadi objek penelitian sebagai variabel bebas atau independent variable adalah sistem pengendalian manajemen, sedangkan variabel terikat atau dependent variable dalam penelitian ini adalah kinerja. Berdasarkan objek penelitian tersebut, maka dalam penelitian ini akan dianalisis mengenai peranan sistem pengendalian manajemen terhadap kinerja di Unit 60
Pembangkitan Saguling. Teknik penelitian yang dilakukan dalam penelitian ini bersifat studi kasus. Metode yang digunakan dalam penelitian ini adalah metode deskriptif dengan pendekatan kualitatif. Data yang digunakan dalam penelitian ini adalah data primer. Data primer bersumber dari hasil observasi, dokumentasi, dan wawancara dengan pejabat berwenang atau bagian lain yang berhubungan dengan permasalahan di Unit Pembangkitan Saguling, yaitu Supervisor Senior Perencanaan Unit dan Kinerja, Supervisor Senior Keuangan dan Pajak, Supervisor Senior Akuntansi dan Anggaran, Supervisor Senior Gudang, Supervisor Senior Administrasi Kepegawaian, Supervisor Pengadaan Barang dan Jasa, Ahli Muda Pengelolaan RJP dan Kinerja, Ahli Muda Keuangan, Pelaksana Senior Keuangan, Ahli Muda Anggaran, dan Ahli Muda Kepegawaian.

\section{HASIL PENELITIAN DAN PEMBAHASAN}

Pelaksanaan Sistem Pengendalian Manajemen pada Unit Pembangkitan Saguling

Struktur Sistem Pengendalian
Manajemen
Berdasarkan bagan organisasi UP
Saguling, bahwa pimpinan tertinggi pada
perusahaan ini adalah pejabat dengan nama
sebutan jabatan General Manager. General


Manager dalam pelaksanaan tugasnya dibantu oleh 4 pejabat dengan nama sebutan jabatan Manajer, yaitu Manajer Operasi dan Pemeliharaan PLTA, Manajer Enjiniring, Manajer Sipil dan Lingkungan, dan Manajer Administrasi. Dengan demikian berdasarkan struktur pengendalian manajemen pada perusahaan ini seperti tergambar pada bagan organisasi, terdapat adanya pusat-pusat pertanggungjawaban berikut uraian tugas, wewenang, dan tanggung jawab untuk setiap fungsi. Keempat Manajer tersebut dalam pelaksanaan tugasnya dibantu oleh pejabat dengan nama sebutan jabatan Supervisor. Selanjutnya Supervisor dalam pelaksanaan teknis pekerjaannya dibantu oleh Staff Ahli dan pegawai sebagai staff pada lingkungan masing-masing Supervisor.

UP Saguling adalah perusahaan berbentuk sebuah organisasi dengan susunan organisasi yang berjenjang, sebagaimana tergambar pada bagan organisasi. Dan terlihat pula pada organisasi perusahaan ini terdapat pusat-pusat pertanggungjawaban. Disamping itu juga telah terciptanya pemisahan fungsi, serta terdapat pembagian tugas, wewenang, dan tanggung jawab sebagaimana terlihat dari job description.

Dan terciptanya pemisahan fungsi sesuai fungsi-fungsi manajemen, yang disertai dengan pembagian tugas, wewenang, dan tanggung jawab. Dengan susunan organisasi yang berjenjang, ini menggambarkan bahwa, perintah merupakan intruksi yang mengalir mulai dari tingkat hierarki tertinggi sampai dengan terendah. Mengalirnya perintah adalah penggerak roda pelaksanaan kegiatan berjalan secara otomatis.

Dengan adanya pembagian tugas, wewenang, dan tanggung jawab pada masing-masing fungsi sebagaimana yang terurai pada job description, maka perusahaan ini memperoleh hal-hal sebagai berikut:

1. Pelaksanaan tugas tidak akan terjadi tumpang tindih.

2. Pelaksana tugas dapat menindaklanjuti tugasnya dengan cepat dan terarah, sehingga penghematan waktu pelaksanaan dengan sendirinya terjadi. Atau dengan kata lain, bahwa efisiensi waktu pelaksanaan pada perusahaan ini tercapai.

3. Petugas pelaksana dalam penyelesaian tugas tidak menimbulkan keraguan. Atau dengan kata lain, seluruh petugas pelaksana tidak saling menunggu dalam penyelesaian pekerjaan. Karena telah diketahuinya tugas masing-masing secara jelas dan tegas.

4. Petugas pelaksana dalam penyelesaian tugas tidak akan terjadi 
melampaui batas-batas kewenangan, karena batas-batas kewenangan masing-masing bagian ditetapkan secara jelas dan tegas.

\section{Proses Sistem Pengendalian Manajemen}

Pada UP Saguling proses sistem pengendalian manajemen yang telah diterapkan yaitu meliputi penyusunan rencana kerja dan anggaran serta pelaksanaan dan evaluasi. Proses sistem pengendalian manajemen dapat terlihat dengan memadai yaitu pada saat pembuatan rencana kerja dan anggaran adalah langkah awal sebagai perencanaan, sebab dengan langkah ini menjadi pedoman pusat proses kegiatan untuk memperoleh kebutuhan dana, juga keperluan pembuatan prosedur pelaksanaan, dan waktu pelaksanaan yang dibutuhkan, serta pembuatan laporan hasil kerja secara tertulis sebagai bahan evaluasi selanjutnya.

\section{a. Penyusunan Rencana Kerja dan}

\section{Anggaran}

Penyusunan rencana kerja dan anggaran pada perusahaan ini berdasarkan hasil wawancara dilakukan secara rutin dan berkala dengan periode satu tahun anggaran. Setiap tahun perusahaan menyusun rencana kerja dan anggaran, dalam penyusunan rencana kerja dan anggaran ini didasari oleh kebijakan dan peraturan yang berlaku. Dengan demikian rencana kerja dan anggaran ini dijadikan pedoman kerja yang harus ditaati oleh seluruh anggota organisasi. Sehingga dengan adanya rencana kerja dan anggaran pada perusahaan, proses pelaksanaan terhindar dari tindakantindakan atas keinginan individu-individu yang tidak berdasarkan kepada rencana yang telah ditetapkan dan peraturan yang berlaku. Rencana kerja dan anggaran mampu mengawal anggota organisasi menuju arah pencapaian tujuan sesuai rencana yang telah ditetapkan.

Dalam penyusunan rencana kerja dan anggaran melibatkan seluruh Manajer dan Supervisor UP Saguling terkait serta Kepala PLTA yang terlibat dalam penyusunan, melakukan penelaahan dan pendalaman terhadap jenis-jenis rencana kerja dan nilainya, guna menghindari terjadinya kekeliruan dan kesalahan, hal ini dilakukan karena RKA dijadikan salah satu alat kendali pelaksanaan operasional perusahaan.

\section{b. Pelaksanaan dan Evaluasi}

Pelaksanaan operasi perusahaan dilakukan berpedoman kepada kebijakan dan prosedur yang telah ditetapkan. Prosedur dalam pelaksanaan kegiatan merupakan wadah sebagai saluran tahapan atau urutan pelaksanaan agar menuju kepada pencapaian tujuan perusahaan. Pada perusahaan ini prosedur yang dijadikan pedoman kerja untuk pekerjaan teknik 
adalah SOP (Standard Operation Procedure) atau IKA (Instruksi Kerja).

Sedangkan untuk pekerjaan administrasi dan keuangan prosedur adalah Tata Cara Proses Administrasi dan Keuangan.

Organisasi UP Saguling dibentuk dengan susunan berjenjang, sehingga instruksi tugas mengalir dari atas ke bawah. Sehingga hasil pelaksanaan tugas yaitu laporan mengalir sebaliknya dari bawah ke atas. Pelaporan adalah data yang berisi informasi mengenai pelaksanaan tugas yang didalamnya terdapat informasi tentang pencapaian target, waktu pelaksanaan, aturan dan prosedur yang dipedomani.

Selanjutnya laporan oleh atasan langsung digunakan sebagai data bahan evaluasi. Proses evaluasi yang dilakukan adalah dengan membandingkan antara laporan sebagai realisasi dengan anggaran yang ditetapkan. Proses membandingkan ini adalah untuk menilai pelaksanaan tugas. Dari hasil penilaian maka atasan pemberi tugas dapat mengetahui tentang hasil pencapaian target dan ketepatan waktu pelaksanaan tugas, kendala-kendala yang dihadapi, serta menilai terhadap peraturan dan prosedur yang digunakan.

Hasil evaluasi ini diperlukan sebagai bahan masukan untuk perbaikan kebijakan, aturan, dan prosedur apabila dipandang kurang mendukung atau kendala terhadap pelaksanaan operasional. Selain itu hasil evaluasi juga sebagai bahan untuk mencari solusi terhadap kendala-kendala yang terjadi dalam pelaksanaan. Dan yang terakhir, untuk mempertimbangkan penetapan reward dan punishment.

\section{Kinerja Unit Pembangkitan Saguling}

Kinerja pada UP Saguling, adalah dilihat dari ukuran kesiapan ketersediaan tenaga listrik, dengan dibuktikan oleh kesiapan mesin pembangkit dalam kondisi prima. Kondisi prima yang dimaksud adalah mesin siap operasi dengan kapasitas maksimum mesin tersebut. Baik tidaknya kinerja pada UP Saguling ditentukan oleh siap tidaknya dalam menciptakan keandalan seluruh unit atau mesin pembangkit dapat dioperasikan. Sehingga mesin-mesin pembangkit tersebut, mampu memproduksi tenaga listrik sesuai dengan kapasitas maksimum yang dimiliki oleh masingmasing mesin pembangkit. Dengan demikian ukuran perusahaan ini berkinerja baik adalah dapat dilihat dari jumlah bruto Kwh yang diproduksi.

Agar tercipta keandalan mesin pembangkit dapat beroperasi sesuai kapasitas maksimum guna tercapai kinerja baik, maka UP Saguling melakukan langkah-langkah sebagai berikut:

1. Predictive maintanance, yaitu monitoring secara rutin seluruh peralatan mesin pembangkit, berikut kondisi reservoir (waduk), aliran sungai yang mengirim air ke waduk, 
dan lingkungan yang mempengaruhi

kelancaran mesin pembangkit beroperasi.

2. Annual inspection, yaitu pengecekan mesin pembangkit secara periodik, pada jam kerja tertentu mesin operasi. Misal ditetapkan jam kerja maksimum mesin beroperasi, pada waktu mesin mencapai $75 \%$ jam kerja maksimum beroperasi, peralatan-peralatan mesin pembangkit dilakukan pengecekan.

3. Major overhoul, adalah perbaikan mesin atau penggantian peralatan pada waktu jam kerja mesin telah mencapai kerja maksimum, sesuai jadwal pemakaian maksimum yang ditetapkan.

Ketiga langkah tersebut adalah dalam rangka menciptakan keandalan unit, sehingga kinerja dapat tercapai.

Selain dikenal dengan adanya kinerja unit, juga adanya kinerja pegawai. Adapun kinerja unit adalah ukuran keandalan unit atau mesin pembangkit dalam kondisi prima dan siap beroperasi maksimum. Sedangkan kinerja pegawai adalah ukuran nihil kecelakaan kerja, tingginya kehadiran pegawai, dan juga tingkat rendahnya biaya kesehatan pegawai.

\section{Peranan Sistem Pengendalian Manajemen terhadap Kinerja Unit Pembangkitan Saguling}

Pada perusahaan ini peranan sistem pengendalian manajemen terhadap kinerja perusahaan sangat erat kaitannya, bahkan sistem pengendalian manajemen adalah penopang pencapaian kinerja perusahaan. Dan agar sistem pengendalian manajemen berperan terhadap kinerja perusahaan, maka perusahaan melakukan langkah-langkah bagi petugas pelaksana agar dalam pelaksanaan operasionalnya terarah kepada pencapaian tujuan perusahaan.

Adapun peran sistem pengendalian manajemen terhadap kinerja perusahaan dapat terlihat dari hal-hal sebagai berikut:

1. Penugasan diberikan kepada pegawai sesuai dengan latar belakang pendidikan dan keterampilan yang dimiliki.

2. Untuk meningkatkan pengetahuan petugas pelaksana, perusahaan mengikut sertakan sebagai peserta diklat (pendidikan dan latihan).

3. Untuk meningkatkan keterampilan dan menambah pengetahuan tentang teknologi baru petugas pelaksana, perusahaan mengirim pegawai terkait untuk mengikuti pelatihan diworkshop mitra kerja atau dilembaga-lembaga lainnya yang menyelenggarakan diklat dengan materi yang sama. 
4. Agar pelaksanaan kerja tercapai sesuai rencana, maka perusahaan membuat metode kerja dan prosedur kerja dan disosialisasikan kepada seluruh petugas pelaksana terkait.

5. Menetapkan petugas pengawas agar pelaksanaan kegiatan mencapai hasil yang diinginkan.

6. Setelah selesai pelaksanaan kegiatan, petugas diharuskan membuat laporan tertulis yang diketahui oleh petugas pengawas.

7. Untuk pelaksana dibidang teknik, sebelum melakukan pekerjaan pengawas selalu mengingatkan tentang penggunaan peralatan keselamatan kerja. Disamping itu juga, disekitar tempat kerja dipasang rambu-rambu tentang pentingnya penggunaan peralatan keselamatan kerja, dan peringatan tentang bahayanya bekerja tidak menggunakan atau tidak dilindungi oleh peralatan keselamatan kerja.

Sebagaimana diuraikan sebelumnya, dapat diketahui bahwa sistem pengendalian manajemen pada perusahaan ini telah dilaksanakan dan dipenuhi dengan memadai. Sehingga dengan langkahlangkah yang diterapkan pada perusahaan ini bahwa sistem pengendalian manajemen telah berperan dalam pencapaian kinerja dengan optimal, sehingga yang diperoleh perusahaan dengan penerapan sistem pengendalian manajemen tersebut adalah:

1. Pada pelaksanaan operasi perusahaan seluruh anggota organisasi mengikuti metode kerja dan mematuhi kebijakan serta peraturan-peraturan yang berlaku. Disamping itu juga dalam kegiatan operasional dilaksanakan sesuai dengan perencanaan dan prosedur yang berlaku.

2. Tugas yang dibebankan kepada pegawai sesuai dengan kompetensi pengetahuannya dan dipenuhinya fasilitas-fasilitas kerja atau peralatan kerja, sehingga dengan demikian pegawai secara emosional kejiwaan menyenangi terhadap pekerjaan yang dihadapi, maka dalam penyelesaian pekerjaan dengan cukup tinggi, juga dapat menciptakan disiplin kerja yang mencerminkan tanggung jawab yang baik terhadap pekerjaan yang dipikul, maupun target waktu penyelesaian pekerjaan dapat terpenuhi sesuai dengan rencana.

3. Dengan terciptanya komunikasi aktif dua arah sehingga tercipta pula suasana kerja yang baik dengan demikian terbentuk kerjasama yang baik, dan berdampak kepada pelaksanaan operasional berjalan dengan lancar. 
Dengan demikian kinerja berperan terhadap kinerja Unit perusahaan pada UP Saguling dapat dicapai, Pembangkitan Saguling. dan pencapaiannya dapat dilihat dari dua kategori kinerja, yaitu:

\section{Saran}

1. Kinerja Unit

Walaupun sistem pengendalian

- Dengan dilakukannya tiga manajemen telah memadai seperti yang langkah, yaitu predictive maintanance, annual inspection, dan major overhoul produksi maksimum tenaga listrik dari setiap mesin pembangkit dapat tercapai, sehingga ketersediaan tenaga listrik terjamin.

- Mesin-mesin pembangkit yang ada selalu berada dalam keadaan kondisi prima siap operasi.

2. Kinerja Pegawai

- Berdasarkan monitoring terhadap data kecelakaan kerja, diperoleh nihil kejadian.

- Kehadiran pegawai khususnya operator mesin pembangkit cukup tinggi.

- Biaya kesehatan pegawai rendah.

\section{SIMPULAN DAN SARAN}

\section{Simpulan}

Berdasarkan hasil penelitian dan pembahasan yang dilakukan, penyusun dapat mengambil kesimpulan bahwa sistem pengendalian manajemen pada Unit Pembangkitan Saguling telah memadai, dan disimpulkan diatas, akan tetapi berdasarkan bagan organisasi pada perusahaan ini tidak terdapat internal audit sebagai pelaksana fungsi pengawasan. Namun demikian pengawasan masih tetap terselenggara yang dilakukan oleh pihak organisasi atasan yaitu Kepala Staff Audit Internal (KSAI) PT Indonesia Power. Oleh karena status KSAI PT Indonesia Power adalah sebagai eksternal auditor apabila dilihat dari elemen organisasi UP Saguling. Sehingga dengan tidak terdapatnya audit internal dalam tubuh UP Saguling, hal ini menjadi beban bagi general manager. Adapun beban-beban tersebut antara lain adalah:

1. General Manager harus memikirkan dan memikul seorang diri masalah pengawasan, karena di internal perusahaan tidak ada rekan kerja dibidang pengawasan.

2. General Manager memikul sendiri dalam melakukan tugas-tugas evaluasi terhadap seluruh operasi perusahaan.

3. General Manager harus mendampingi dan memonitor Auditor Eksternal pada waktu pemeriksaan oleh dirinya sendiri, 
karena tidak ada pejabat setingkat manajer bidang pengawasan.

Dengan maksud agar beban-beban tersebut dapat teratasi sehingga efektivitas dan efisiensi tercapai, maka penyusun menyarankan pimpinan tertinggi pada UP Saguling, untuk melakukan tindakantindakan sebagai berikut:

1. General Manager agar menetapkan petugas yang melakukan tugas-tugas evaluasi terhadap laporan-laporan yang dibuat oleh seluruh pusat-pusat pertanggungjawaban sebagai bentuk pertanggungjawaban atas pelaksanaan tugas, hal ini bertujuan untuk mendeteksi permasalahan/penyimpangan secara dini.

Karena apabila terjadi kekeliruan dapat dengan cepat diketahui, dan dengan cepat pula dilakukan koreksi-koreksi sebagaimana mestinya. Karena semakin lama ditemukan kekeliruan/kesalahan, maka makin sulit dilakukan koreksi sebagai perbaikan.

2. General Manager agar menetapkan satu petugas atau lebih yang memiliki pengetahuan dibidang pengawasan, yang mampu bertindak sebagai rekan kerja yang dapat memberi masukan tentang pengawasan, dan juga sebagai pendamping Auditor Eksternal apabila General Manager sedang melakukan dinas luar. Hal ini diperlukan untuk menghindari terjadinya miscommunication dan misinterpretation antara petugas terperiksa dengan Auditor Eksternal.

3. Setelah ditetapkan petugas, selanjutnya petugas tersebut dibekali pengetahuan pengawasan untuk menunjang kelancaran tugas, melalui pendidikan dan latihan milik PT PLN (Persero) yang ada, ataupun lembaga kursus lainnya.

4. Untuk memperingan beban tugas General Manager khususnya dalam mengawasi penggunaan dan pengelolaan keuangan dan material, maka SPS Akuntansi dan Anggaran agar diberi lebih dalam mengevaluasi dengan maksud agar tercipta deteksi dini terhadap penggunaan dan pengelolaan keuangan dan material.

\section{DAFTAR PUSTAKA}

Anthony, Robert N. and Vijay Govindarajan. (2005) "Management Control System", Buku 1, Edisi 11, Penerjemah F.X. Kurniawan Tjakrawala dan Krista, Jakarta: Salemba Empat.

Arikunto, Suharsimi. (2011) "Prosedur Penelitian Suatu Pendekatan Praktik”, Jakarta: Rineka Cipta. 
Djakatara, Faisal. (2013) "Pengaruh Sistem Pengendalian Manajemen terhadap Kinerja Perusahaan pada PT PLN (Persero) Cabang Gorontalo”, Jurusan Akuntansi, Fakultas Ekonomi dan Bisnis, Universitas Negeri Gorontalo.

Halim, Abdul, Achmad Tjahjono, dan Muh.

Fakhri Husein. 2003. Sistem Pengendalian Manajemen.

Yogyakarta: UPP AMP YKPN.

Majed, Gani Abdel. (2013) "Pengaruh Sistem Pengendalian Manajemen dan Implementasi Manajemen Kualitas terhadap Kinerja Perusahaan, Jurnal Akuntansi, Universitas Negeri Padang, Vol. 1 No. 3.

Mangkunegara, Anwar Prabu. (2009)

"Evaluasi Kinerja Sumber Daya Manusia”, Bandung: Refika Aditama.

Porporato, Marcela. (2006) "Impact of Management Control System' Intensity of Use on Joint Venture's Performance: an Empirical Assessment", Journal of Management Control System, Vol. 21: p.512-562.

Pusat Pendidikan dan Pelatihan Pengawasan Badan Pengawasan Keuangan dan Pembangunan (BPKP). (2009) "Pengantar Sistem Pengendalian Manajemen", Edisi Kelima, Ciawi.
Rukmana, Teguh, Epi Fitriah, dan Yuni Rosdiana. (2015) "Analisis Penerapan Sistem Pengendalian Manajemen terhadap Kinerja Manajerial di PT Dirgantara Indonesia", Ekonomi, Akuntansi, Universitas Islam Bandung.

Ruky, Achmad S. (2004) "Sistem Manajemen Kinerja” Cetakan ketiga, Jakarta: PT. Gramedia Pustaka Utama.

Saudi, Arif. (1996) "Sistem Pengendalian Manajemen", Edisi Pertama, Buku 1, Yogyakarta: BPFE.

Sugiyono. (2017) "Metode Penelitian Bisnis Kuantitatif Kualitatif dan R\&D”, Bandung: Alfabeta.

Supriyono, R.A. (2000) "Sistem Pengendalian Manajemen", Edisi Pertama, Yogyakarta: BPFE.

Tatikonda, Laksmi U dan Rao J. Tatikonda. (1998) "We Need Dynamic Performance Measure Measures", Majalah Manajemen.

Yustien, Reni, Andi Mirdah, dan Ratih Kusumastuti. (2013) "Pengaruh Penerapan Struktur Pengendalian Manjemen Melalui Proses Pengendalian Manajemen terhadap Kinerja Manajerial pada Rumah Sakit Pemerintah di Kota Jambi”, Fakultas Ekonomi Universitas Jambi. 
Zhang Man dan McCullough James. (2001)

"Effect of Learning and Information

Technology Capability on Business

Performance", Washington State

University, USA. 
JAFTA - Vol 3 Nomor 1, Maret (2021) 